\title{
Stunting Prevention with Education and Nutrition in Pregnant Women: A Review of Literature
}

\author{
Sukmawati Sukmawati ${ }^{1,2 *(\mathbb{D})}$, Yanti Hermayanti ${ }^{1} \mathbb{D}$, Eddy Fadlyana $^{3}$, Henny Suzana Mediani $^{4}$ (D) \\ ${ }^{1}$ Doctoral Study Program, Faculty of Medicine, Universitas Padjadjaran, Bandung, Indonesia; ${ }^{2}$ Department of Maternity, Faculty \\ of Nursing, Universitas Padjadjaran, Bandung, Indonesia; ${ }^{3}$ Department of Pediatric, Faculty of Medicine, Universitas Padjadjaran, \\ Bandung, Indonesia; ${ }^{4}$ Department of Pediatric Nursing, Faculty of Nursing, Universitas Padjadjaran, Bandung, Indonesia
}

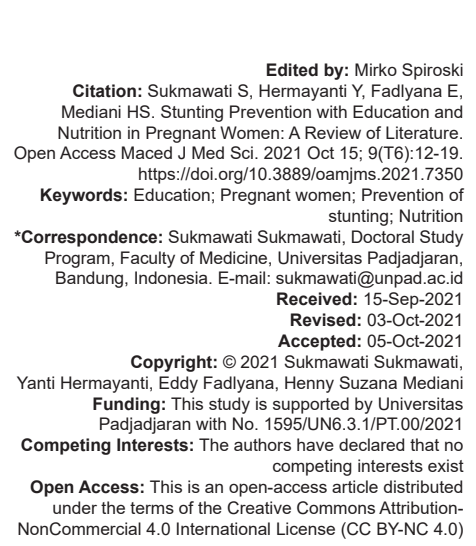

\section{Introduction}

Stunting is still a major nutritional problem experienced by children under five globally. In 2017, around 150.8 million or $22.2 \%$ of children under five in the world experienced stunting, 55\% occurred in Asia. More than a third (39\%) occurred in Africa. The stunting rate for children under five in Asia is highest in southern Asia (58.7\%), while the lowest rate is in central Asia (0.9\%) [1]. According to the WHO, Indonesia is the third country with the highest prevalence of stunting children under 5 years in the Southeast Asia Region. The average prevalence of stunting children under 5 years in Indonesia in 2005-2017 is $36.4 \%$. The prevalence of stunting children under 5 years has increased from 2016 which is $27.5 \%$ and in 2017 to $29.6 \%$. The region of Indonesia with the highest prevalence of stunting at the age of 0-59 months in 2017 was in the province of East Nusa Tenggara, while the lowest prevalence was in the Province of Bali [1].

Stunting is a growth disorder that is widely used to measure the nutritional status of individuals or communities [2]. Stunting is a condition where children under five have a length or height that is less than normal compared to their age [1]. According to the National Center of Health Statistics United States said that linear growth that does not reach the growth average for the age group and gender is referred to as malnutrition [2].

The causes of stunting in children are low energy intake (93.5\%), infectious diseases (80.6\%), low protein intake $(45.2 \%)$, not given exclusive breastfeeding (32.3\%), and working mothers (29.0\%) [3]. Stunting is also influenced by a history of low birth weight. Babies born with low birth weight are much influenced by factors of low maternal nutrition during pregnancy [2]. The results of the search Yusnita et al.'s (2020) showed that iron and folic acid consumed by mothers during pregnancy were associated with the incidence of stunting in children at the age of 0-24 months [4]. Stunting also affected by infectious diseases, environmental sanitation, family food supply, health care and immunization, lack of knowledge of the mother, lack of education, and family income [5]. Chronic Energy Deficiency (KEK) due to insufficient 
energy and protein intake in pregnant women can also cause a small amount of nutrients received by the fetus and when the fetus is born its physical growth will experience delays, low cognitive abilities due to impaired brain growth, and the risk of stunting [6].

Pregnant women are a group that is vulnerable to nutritional problems; this is related to the process of fetal growth and the growth of various organs of the body as a supporter of the pregnancy process. Pregnant women need additional energy, protein, vitamins, and minerals to support fetal growth and the body's metabolic processes [7]. The role of education and nutrition is important in pregnancy because it has implications for the health of mothers and children in later life. Optimal nutrition, if maintained throughout pregnancy, promotes optimal fetal growth and development [8]. Calorie intake should increase by about $300 \mathrm{kcal} / \mathrm{day}$ during pregnancy. This value is derived from the estimated 80,000 kcal required to support pregnancy [9].

The increase in energy needs mainly occurs in the second and third trimesters, the additional energy consumption in the second trimester is needed for the growth of maternal tissues such as increasing blood volume, uterine and breast growth, and fat accumulation. The addition of energy consumption in the third trimester is used for fetal and placental growth [10]. The purpose of this review article was to determine the effect of stunting prevention through education and nutrition on pregnant women.

\section{Materials and Methods}

\section{Searching strategy}

The initial search was conducted through three databases, namely, PubMed, CINAHL, Google scholar from 2011 to 202 . The keywords used for search were: Pregnant women and stunting prevention prevention of stunting with education and nutrition for pregnant women. The method and results of this literature review were based on PRISMA (Figure 1). The search terms used were: Nutrition AND (pregnancy OR pregnant OR prenatal OR antenatal) AND stunting AND prevention AND education. Hand searching was conducted to provide relevancy study results, especially studies from Asian countries. The studies included in this review were studies written in English and Bahasa Indonesia.

\section{Inclusion criteria}

The criteria inclusion included in the study were: (1) Article using randomized controller trials, retrospective, cross-sectional and quasi-experimental cohort studies, (2) evaluating the results of

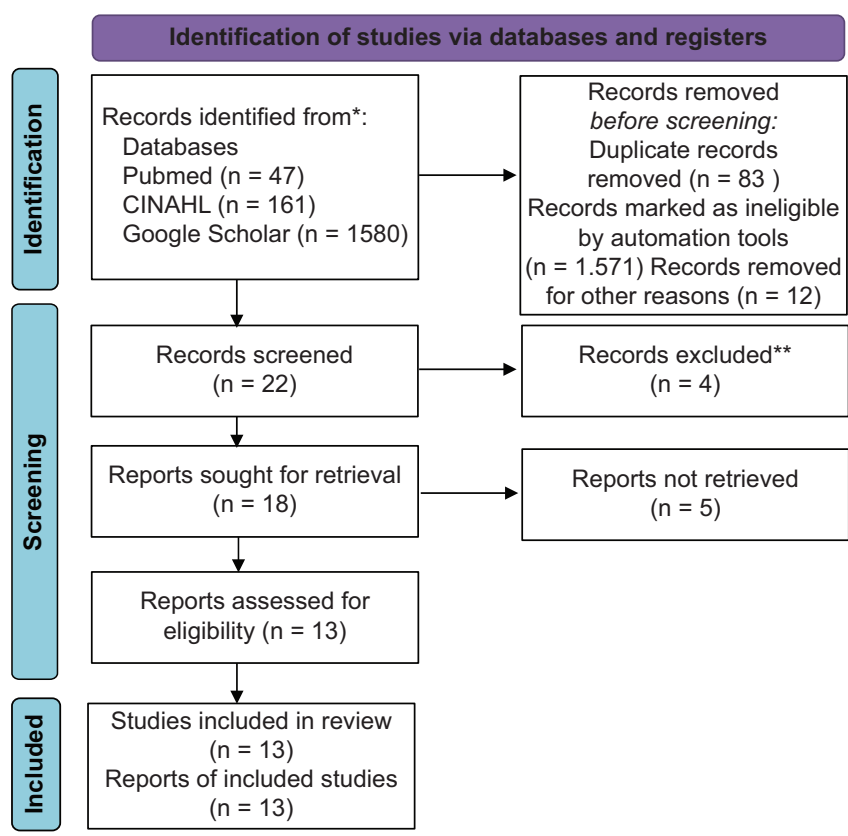

Figure 1 PRISMA

education for pregnant women to prevent stunting, and (3) evaluating nutrition for pregnant women to prevent stunting. A study was excluded if: (1) It did not have the full text available, and (2) it was a primary study.

\section{Search outcome}

In the first phase, 1788 articles were obtained, where 83 of them were duplicated. In the next phase, titles and abstracts were selected so that 22 articles corresponding to the population and the concept of this review were obtained. Full-text reading was then conducted to exclude articles that did not meet the inclusion criteria and/or have established exclusion criteria. At this phase, 13 articles were included in the next phase, which was quality appraisal. This final phase obtained nine studies that met the criteria for synthesis. The selection phase is explained in detail using the PRISMA flow diagram, as shown in Figure 1.

\section{Quality appraisal}

To assess the quality of research, the researcher used a critical assessment from the Joanna Briggs Institute [11]. The tools of each research method consist of four categories of answers: Yes, no, unclear, and not applicable. For yes answers are given a value of " 1 " and for no answers give a value of " 0 ," then it is calculated and if the score is more than $50 \%$ then the article is eligible for analysis.

\section{Data extraction and analysis}

Relevant data were taken from the extracted research, including (1) the main author and year of 
publication, (2) the objectives, (3) the country of the population studied, (4) the study design, (5) the sample size, (6) the data collection method, and (7) the results of the study.

\section{Results}

\section{Search results}

This review analyzed education and nutrition for pregnant women to prevent stunting. A total of 1.788 published articles were identified. After the initial screening 83 articles were removed for duplication, 1.571 articles were removed for not meeting the criteria and 12 articles were removed for other reasons leaving 22 articles. Four articles were excluded and four articles were not taken and after complete screening only 13 articles were analyzed.

\section{Study characteristics}

The study characteristics and the main study findings of this study are summarized in Table 1. There were 13 studies conducted in 11 different countries; Indonesia $(n=5)$, Nepal $(n=1)$, Bangladesh $(n=3)$, Guatemala $(n=1)$, India dan Pakistan $(n=1)$, Afghanistan, Bangladesh, Butan, India, and Maldives dan Pakistan ( $n=1)$ dan Burundi ( $n=1)$.

The findings from the main studies are summarized in Table 1. There were 13 studies conducted in 11 different countries; most of the research was conducted on pregnant women $(n=7)$, pregnant women and newborns as well as pregnant women and children under two $(n=5)$. Most of the studies had a randomized control trial $(\mathrm{RCT})(\mathrm{n}=7)$, cross-sectional ( $n=1)$, quasi-experimental $(n=3)$, retrospective $(n=1)$, and experimental $(n=1)$ cohort. The sample size ranged from 15 to 96,512 respondents. The main results selected in the study we found three articles on providing education and ten provision of nutrition and supplements to prevent stunting.

\section{Education and nutrition for pregnant women for prevent stunting}

The selected articles were analyzed one by one, three articles found that education for pregnant women can increase mother's knowledge to prevent stunting and ten articles on nutrition and supplements can prevent stunting. The results of the analysis of each article are shown in Table 1.
Based on the articles that have been analyzed, the results obtained are 13 articles on stunting prevention based on education and nutrition consumed by the mother during pregnancy which is divided into several categories, namely education and providing supplements/nutrition.

\section{Education}

\section{Education used audio-visual media}

Education using audiovisual media has an effect on increasing the knowledge of pregnant women about stunting prevention. The results of this study are in line with the results of Yoga (2020), namely, the need to strengthen and expand the scope of sensitive nutrition programs related to stunting (water, food, sanitation, education, infrastructure, service access, and the economy) and the results of the study show that there is an effect of knowledge after being given intervention and description of consumption of non-nutritious food, and smoking status in husbands [24]. Continuous education and monthly monitoring are needed in monitoring the diet of pregnant women during pregnancy classes at the Posyandu. In line with statement Khatiwada et al. (2021) potential knowledge gaps and barriers to acceptance and help develop effective educational messages to raise awareness, reduce negativity, and promotion health services [25].

\section{Moringa leaf ice cream innovation product}

Moringa leaves for pregnant Moringa Ice Cream: Product Innovation as an Effort to Prevent Stunting in the First 1000 Days of Life (Hpk) in pregnant women. This study aims to provide an understanding of the importance of nutrition from the manufacture of Moringa flour into Moringa ice cream products along with the methods and methods of marketing it with the result that people know more about the nutritional content of Mwomen and innovate by learning how to make and market it [13]. Based on the results of Aminah's research (2015), Moringa leaves contain elements of micronutrients that are needed by pregnant women, such as beta carotene, thiamin (B1), riboflavin (B2), niacin (B3), calcium, iron, phosphorus, magnesium, zinc, and Vitamin C, as an alternative to improve the nutritional status of pregnant women [26].

\section{nutrition food}

Prevention of stunting from an early age with

The purpose of this research is to increase the knowledge of pregnant women regarding the need for good nutrition during pregnancy and increase the skills of pregnant women in managing nutrient-rich foods. 
Table 1: Article summary

\begin{tabular}{|c|c|c|c|c|c|c|c|}
\hline No & Title & Objective study & Place & Design & Subject & Data collection techniques & Findings \\
\hline 1 & $\begin{array}{l}\text { The effect of } \\
\text { audiovisual } \\
\text { media education } \\
\text { in knowledge of } \\
\text { stunting prevention } \\
\text { in pregnant } \\
\text { women [12] }\end{array}$ & $\begin{array}{l}\text { To know the description of food } \\
\text { consumption, motivation of } \\
\text { pregnant women and smoking } \\
\text { behavior as well as changes } \\
\text { in knowledge after being given } \\
\text { education trough audiovisual } \\
\text { media }\end{array}$ & $\begin{array}{l}\text { Cibatok Village } \\
2 \text { Bogor } \\
\text { Indonesia }\end{array}$ & $\begin{array}{l}\text { Quasi } \\
\text { experimental }\end{array}$ & 17 pregnant women & $\begin{array}{l}\text { Pregnant women } \\
\text { are given education } \\
\text { used audiovisua. } \\
\text { Measurements were taken } \\
\text { before and after education }\end{array}$ & $\begin{array}{l}\text { Audiovisual education is proven to } \\
\text { increase knowledge of stunting from } \\
50 \% \text { to } 78.6 \%\end{array}$ \\
\hline 2 & $\begin{array}{l}\text { Moringa oleifera } \\
\text { ice cream: An } \\
\text { innovation product } \\
\text { as prevention of } \\
\text { stunting in the first } \\
1000 \text { days of life [13] }\end{array}$ & $\begin{array}{l}\text { To increase knowledge about } \\
\text { the importance of nutrition from } \\
\text { Moringa flour into Moringa ice } \\
\text { cream products along with } \\
\text { the methods and marketing to } \\
\text { prevent stunting }\end{array}$ & $\begin{array}{l}\text { Jember } \\
\text { Indonesia }\end{array}$ & Eksperimen & 15 pregnant women & Observation and training & $\begin{array}{l}\text { There is an increase in the average } \\
\text { value of knowledge pre-test } 74.6 \\
\text { and post-test } 96\end{array}$ \\
\hline 3 & $\begin{array}{l}\text { Prevention stunting } \\
\text { from an early age } \\
\text { with nutritious } \\
\text { food for pregnant } \\
\text { women [14] }\end{array}$ & $\begin{array}{l}\text { To increase the knowledge of } \\
\text { pregnant women regarding the } \\
\text { need for good nutrition during } \\
\text { pregnancy and increase the } \\
\text { skills of pregnant wo men in } \\
\text { managing nutrient-rich foods }\end{array}$ & Indonesia & $\begin{array}{l}\text { Education with } \\
\text { lectures and } \\
\text { demonstrations }\end{array}$ & 40 pregnant women & Food recall technique & $\begin{array}{l}\text { There is an improvement in the diet } \\
\text { of pregnant women after being given } \\
\text { education with food recall. There } \\
\text { is an increase in knowledge about } \\
\text { nutrition as indicated by the accuracy } \\
\text { of pregnant women in answering } \\
\text { questions from health wokers }\end{array}$ \\
\hline 4 & $\begin{array}{l}\text { Tubaramure, a } \\
\text { Food-Assisted } \\
\text { Integrated } \\
\text { Health and Nutrition } \\
\text { Program, Reduces } \\
\text { Child } \\
\text { Stunting [15] }\end{array}$ & $\begin{array}{l}\text { To assessed the impact } \\
\text { of Burundi's Tubaramure } \\
\text { FA-MCHN program on linear } \\
\text { growth }\end{array}$ & Burundi & $\begin{array}{l}\text { Randomized } \\
\text { Controlled Trial }\end{array}$ & $\begin{array}{l}3500 \text { women and } \\
\text { their children during } \\
\text { the first } 1000\end{array}$ & Survey & $\begin{array}{l}\text { Tubaramure had a significant } \\
(p<0.05) \text { beneficial effect in the } \\
\text { T24 }(7.4 \text { percentage points }[p p] ; \\
p<0.05), T 18(5.7 p p ; p<0.05) \text {, } \\
\text { and TNFP }(4.6 ; p=0.09) \text { arms; the } \\
\text { differences in effect across arms } \\
\text { were not significant }(p>0.01) \text {. } \\
\text { Secondary analyses showed that the } \\
\text { effect was limited to children whose } \\
\text { mother and head of household had } \\
\text { some primary education and who } \\
\text { lived in households with above- } \\
\text { median assets. }\end{array}$ \\
\hline 5 & $\begin{array}{l}\text { Effect of } \\
\text { Moringa Oleifera } \\
\text { Supplementation } \\
\text { during Pregnancy } \\
\text { on The Prevention } \\
\text { of Stunting Growth } \\
\text { in Children between } \\
\text { The Ages of 36-42 } \\
\text { months [16] }\end{array}$ & $\begin{array}{l}\text { To assessed the effect of } \\
\text { moringa intervention during } \\
\text { pregnancy on the incidence } \\
\text { of stunted growth in children } \\
\text { between the ages of } 36-42 \\
\text { months }\end{array}$ & $\begin{array}{l}\text { South Sulawesi, } \\
\text { Indonesia }\end{array}$ & $\begin{array}{l}\text { Experimental } \\
\text { randomized } \\
\text { control trial- } \\
\text { double blind } \\
\text { (RCT-DB }\end{array}$ & $\begin{array}{l}4403^{\text {rd }} \text { trimester } \\
\text { pregnant women } \\
\text { will able to give birth } \\
\text { was } 440 \text { (single } \\
\text { wombs), However, } \\
\text { in the age range of } \\
\text { children between } 0 \\
\text { and } 36 \text { months, the } \\
\text { respondents pulled } \\
\text { out of the research } \\
\text { leaving the total } \\
\text { number of children } \\
\text { that survived to } 340 \\
\text { children. }\end{array}$ & Observation and interview & $\begin{array}{l}\text { The EG extract was effective in } \\
\text { reducing the incidence of stunting } \\
(p<0.005) \text { and as a protective } \\
\text { factor by } 0.431 \text { times the incidence } \\
\text { of stunting (LLUL }=0.246-0.754) \text {. }\end{array}$ \\
\hline 6 & $\begin{array}{l}\text { Iron-Folic Acid } \\
\text { Supplementation } \\
\text { During Pregnancy } \\
\text { Reduces the Risk of } \\
\text { Stunting in Children } \\
<2 \text { Years of Age: } \\
\text { A Retrospective } \\
\text { Cohort Study [17] }\end{array}$ & $\begin{array}{l}\text { To investigate the effect of } \\
\text { antenatal iron-folic acid (IFA) } \\
\text { supplementation on child } \\
\text { stunting in Nepalese children } \\
\text { age }<2 \text { years }\end{array}$ & Nepal & $\begin{array}{l}\text { Studi kohort } \\
\text { retrospektif }\end{array}$ & $\begin{array}{l}5235 \text { most recent live } \\
\text { births } 2 \text { years prior }\end{array}$ & $\begin{array}{l}\text { Interview from three Nepal } \\
\text { Demographic and Health } \\
\text { Surveys }(2001,2006 \text { and } \\
\text { 2011) }\end{array}$ & $\begin{array}{l}\text { The adjusted relative risk of } \\
\text { being stunted was } 14 \% \text { lower } \\
\text { in children whose mothers used } \\
\text { IFA supplements compared to } \\
\text { those whose mothers did not use } \\
\text { (aRR }=0.86,95 \% \mathrm{Cl}=0.77-0.97 \text { ). } \\
\text { Additionally, the adjusted } \\
\text { relative risk of being stunted was } \\
\text { significantly reduced by } 23 \% \text { when } \\
\text { antenatal IFA supplementation was } \\
\text { started } \leq 6 \text { months with } \geq 90 \text { IFA } \\
\text { supplements used during pregnancy } \\
\text { (aRR }=0.77,95 \% \mathrm{Cl}=0.64-0.92 \text { ). } \\
\text { Antenatal IFA supplementation } \\
\text { significantly reduced the risk of } \\
\text { stunting in Nepalese children age } \\
<2 \text { years. The greatest impact on } \\
\text { the risk reduction of child stunting } \\
\text { was when IFA supplements were } \\
\text { started } \leq 6 \text { months with } \geq 90\end{array}$ \\
\hline 7 & $\begin{array}{l}\text { The Relationship of } \\
\text { Maternal Specific } \\
\text { Nutritional Factors } \\
\text { with The incidence } \\
\text { of Stunting [4] }\end{array}$ & $\begin{array}{l}\text { To determine specific nutritional } \\
\text { factors in mothers with the } \\
\text { incidence of stunting }\end{array}$ & Indonesia & $\begin{array}{l}\text { Analitical } \\
\text { descriptive with } \\
\text { cross sectional }\end{array}$ & $\begin{array}{l}789 \text { pregnant women } \\
\text { and children under } \\
2 \text { years }\end{array}$ & $\begin{array}{l}\text { Measurement of height } \\
\text { using a microtoa } \\
\text { questionnaire for the } \\
\text { characteristics of the } \\
\text { child and mother, and } \\
\text { specific nutritional factors } \\
\text { for the mother, namely } \\
\text { receiving folic acid } \\
\text { and Fe supplements } \\
\text { during pregnancy, } \\
\text { exclusive breastfeeding } \\
\text { counseling and counseling } \\
\text { complementary foods for } \\
\text { breastfeeding }\end{array}$ & $\begin{array}{l}\text { There is a relationship between the } \\
\text { administration of Folic Acid and Fe } \\
\text { supplements with the occurrence of } \\
\text { stunting } p \text { value } 0,000\end{array}$ \\
\hline
\end{tabular}


Table 1: (Continued)

\begin{tabular}{|c|c|c|c|c|c|c|c|}
\hline No & Title & Objective study & Place & Design & Subject & Data collection techniques & Findings \\
\hline 8 & $\begin{array}{l}\text { Lipid-based nutrient } \\
\text { supplements for } \\
\text { pregnant women } \\
\text { reduce newborn } \\
\text { stunting in a } \\
\text { cluster-randomized } \\
\text { controlled } \\
\text { effectiveness } \\
\text { trial [18] }\end{array}$ & $\begin{array}{l}\text { To evaluated the effect of lipid- } \\
\text { based nutrient supplements for } \\
\text { pregnant and lactating women } \\
\text { (LNS-PLs) on birth }\end{array}$ & Bangladesh & $\begin{array}{l}\text { Randomized } \\
\text { controlled trials }\end{array}$ & $\begin{array}{l}4011 \text { pregnant } \\
\text { womwn with } \\
20 \text { weeks gestation }\end{array}$ & $\begin{array}{l}\text { To performed by } 2 \\
\text { separate teams: the "SDU } \\
\text { visit team," which collected } \\
\text { clinical and anthropometric } \\
\text { data at the SDU, and } \\
\text { the "home visit team," } \\
\text { which enrolled mothers } \\
\text { and collected baseline } \\
\text { and follow-up data at } \\
\text { participants' homes. }\end{array}$ & $\begin{array}{l}\text { Infants in the LNS-PL group had } \\
\text { higher birth weights, weight-for-age } \\
z \text { scores, head-circumference-for- } \\
\text { age } z \text { scores and body mass index } \\
z \text { scores }(p<0.05) \text {. The effects of } \\
\text { LNS-PL on newborn stunting were } \\
\text { greatest in infants born before } \\
\text { a } 10 \text {-wk interruption in LNS-PL } \\
\text { distribution ( } n=1301 ; 15.7 \%)\end{array}$ \\
\hline 9 & $\begin{array}{l}\text { PROCOMIDA, } \\
\text { a Food-Assisted } \\
\text { Maternal and Child } \\
\text { Health and Nutrition } \\
\text { Program, Reduces } \\
\text { Child Stunting } \\
\text { in Guatemala: A } \\
\text { Cluster-Randomized } \\
\text { Controlled } \\
\text { Intervention } \\
\text { Trial [19] }\end{array}$ & $\begin{array}{l}\text { To evaluated the impact } \\
\text { of an FA-MCHN program, } \\
\text { PROCOMIDA, on linear growth } \\
\text { (stunting [length-for-age } z \text { score } \\
\text { (LAZ)<-2] and length-for-age } \\
\text { difference [LAD]) among children } \\
\text { aged } 1-24 \text { mo. PROCOMIDA } \\
\text { was implemented in Guatemala } \\
\text { by Mercy Corps and was } \\
\text { available to beneficiaries } \\
\text { throughout the first } 1000 \text { day }\end{array}$ & Guatemala & $\begin{array}{l}\text { Randomized } \\
\text { controlled trials }\end{array}$ & $\begin{array}{l}\text { All pregnant } \\
\text { women served by } \\
\text { PROCOMIDA's } 100 \\
\text { health convergence } \\
\text { centers are eligible. } \\
120 \text { (out of } 215 \text { ) } \\
\text { eligible health } \\
\text { convergence centers } \\
\text { were stratified by } \\
\text { size and randomly } \\
\text { assigned to } 1 \text { of } 6 \\
\text { study groups. }\end{array}$ & Survey and interview & $\begin{array}{l}\text { It was possible to significantly } \\
\text { improve linear growth and reduce } \\
\text { stunting in the first } 1000 \text { day } \\
\text { through a well-designed FA-MCHN } \\
\text { program that targeted mothers } \\
\text { during pregnancy and the child up } \\
\text { to } 24 \text { mo of age. }\end{array}$ \\
\hline 10 & $\begin{array}{l}\text { Preconception } \\
\text { nutrition intervention } \\
\text { improved birth } \\
\text { length and } \\
\text { reduced stunting } \\
\text { and wasting in } \\
\text { newborns in South } \\
\text { Asia: The Women } \\
\text { First Randomized } \\
\text { Controlled Trial [20] }\end{array}$ & $\begin{array}{l}\text { To determine the extent to } \\
\text { which maternal nutrition } \\
\text { interventions commenced } \\
\text { before conception or in the 1st } \\
\text { trimester improved fetal growth }\end{array}$ & $\begin{array}{l}\text { India dan } \\
\text { Pakistan }\end{array}$ & $\begin{array}{l}\text { Randomized } \\
\text { controlled trials }\end{array}$ & 972 newborns & Observation & $\begin{array}{l}\text { Giving nutrition to mothers before } \\
\text { pregnancy or in the } 1 \text { st trimester } \\
\text { of pregnancy can reduce stunting } \\
(44 \%) \text {, wasting ( } 24 \%) \text { and SGA } \\
(26 \%) \text { in newborns compared to the } \\
\text { control group. }\end{array}$ \\
\hline 11 & $\begin{array}{l}\text { Antenatal } \\
\text { Iron-Folic Acid } \\
\text { Supplementation } \\
\text { Is Associated with } \\
\text { Improved Linear } \\
\text { Growth and Reduced } \\
\text { Risk of Stunting or } \\
\text { Severe Stunting in } \\
\text { South Asian Children } \\
<2 \text { Years of Age: A } \\
\text { Pooled Analysis from } \\
\text { Seven Countries [21] }\end{array}$ & $\begin{array}{l}\text { To assessed the effect of } \\
\text { WHO-recommended antenatal } \\
\text { iron, and folic acid (IFA) } \\
\text { supplements on smaller than } \\
\text { average birth size and stunting } \\
\text { in South Asian children <2 } \\
\text { years old }\end{array}$ & $\begin{array}{l}\text { Afghanistan, } \\
\text { Bangladesh, } \\
\text { Bhutan, India, } \\
\text { Maldives, } \\
\text { Nepal, dan } \\
\text { Pakistan }\end{array}$ & $\begin{array}{l}\text { Quasi } \\
\text { Eksperimen }\end{array}$ & $\begin{array}{l}96,512 \text { mothers with } \\
\text { their most recent } \\
\text { birth within } 2 \text { years, } \\
\text { from nationally } \\
\text { representative } \\
\text { surveys between } \\
2005 \text { and } 2016 \text { in } \\
\text { seven South Asian } \\
\text { countries } 96.512\end{array}$ & Observation & $\begin{array}{l}\text { Used of antenatal IFA was } \\
\text { associated with a reduced adjusted } \\
\text { risk of being stunted by } 8 \% \text { (aRR } \\
0.92,95 \% \mathrm{Cl} 0.89,0.95 \text { ), of being } \\
\text { severely stunted by } 9 \% \text { (aRR } 0.91 \text {, } \\
95 \% \mathrm{Cl} 0.86,0.96 \text { ) and of being } \\
\text { smaller than average birth size by } \\
14 \% \text { (aRR } 0.86,95 \% \mathrm{Cl} 0.80,0.91 \text { ). }\end{array}$ \\
\hline 12 & $\begin{array}{l}\text { Lipid-based nutrient } \\
\text { supplementation } \\
\text { in the first } 1000 \\
\text { day improves } \\
\text { child growth in } \\
\text { Bangladesh: a } \\
\text { cluster-randomized } \\
\text { effectiveness } \\
\text { trial [22] }\end{array}$ & $\begin{array}{l}\text { To evaluate the effect of lipid- } \\
\text { based nutrient supplements for } \\
\text { pregnant and lactating women } \\
\text { (LNS-PLs) on birth outcomes }\end{array}$ & Bangladesh & $\begin{array}{l}\text { Cluster- } \\
\text { randomized } \\
\text { effectiveness } \\
\text { trial }\end{array}$ & $\begin{array}{l}4011 \text { pregnant } \\
\text { women at } \leq 20 \\
\text { gestational weeks; } \\
48 \text { clusters received } \\
\text { iron and folic acid } \\
\text { (IFA; } 60 \mathrm{mg} \text { Fe }+400 \\
\mu \mathrm{g} \text { folic acid) and } \\
16 \text { clusters received } \\
\text { LNS-PLs ( } 20 \mathrm{~g} / \mathrm{d} \text {, } \\
118 \text { kcal) containing } \\
\text { essential fatty acids } \\
\text { and } 22 \text { vitamins and } \\
\text { minerals }\end{array}$ & Observation & $\begin{array}{l}\text { Giving LNS-PLs to pregnant women } \\
\text { can increase body weight, head } \\
\text { circumference, body mass index } \\
\text { and reduced risk of new born } \\
\text { p value }<0.05\end{array}$ \\
\hline 13 & $\begin{array}{l}\text { Effects of } \\
\text { prenatal multiple } \\
\text { micronutrient } \\
\text { supplementation } \\
\text { on growth and } \\
\text { cognition through } 2 \\
\text { years of age in rural } \\
\text { Bangladesh: the } \\
\text { JiVitA-3 Trial [23] }\end{array}$ & $\begin{array}{l}\text { To assessed the effects of } \\
\text { prenatal multiple micronutrient } \\
\text { (MM) supplementation on } \\
\text { child growth and cognitive } \\
\text { developmen }\end{array}$ & Bangladesh & $\begin{array}{l}\text { Cluster } \\
\text { Randomized } \\
\text { Control Trial }\end{array}$ & $\begin{array}{l}8529 \text { children with } \\
\text { a subsample of } \\
754 \text { from newborns } \\
\text { to children aged } \\
24 \text { months }\end{array}$ & Observation & $\begin{array}{l}\text { Giving multiple micronutrient to } \\
\text { mothers before and after giving } \\
\text { birth can increase LAZ to reduced } \\
\text { stunting until the age of } 4-4 \text { months } \\
(p<0.001)\end{array}$ \\
\hline
\end{tabular}

This study shows that the demonstration and practice method provides better benefits than counseling alone, besides that it is more beneficial in increasing mother's knowledge in feeding practices, meal preparation, amount of food, energy intake and protein intake so that it can increase nutritional intake. In line with the results of Yunitasari et al. (2021) research that knowledge, attitudes, income, cultural values, and parenting patterns affect parents' strategies in preventing stunting in their children, stunting prevention should focus on improving parental behavior by modifying these factors [27].

\section{Supplementation/Nutrition}

Tubaramure, a food-assisted integrated health and nutrition program

The Tubaramure Food-Assisted Integrated Health and Nutrition program has an impact on reducing stunting in children. Based on the intervention, the research sample was divided into a control group and an intervention group. Nutrition was given to the intervention group who were given food support with types of food consisting of corn, soybeans, and vegetable oil rich in micronutrients which were given for the first 1000 days 
starting when the mother was pregnant and continued until the child's age reached 24 months. Provision of nutrition is more influential than the control group, which is only given access to health services and the provision of health education [15].

\section{Moringa oleifera supplementation}

Moringa leaf extract given during pregnancy is proven to be more effective in preventing stunting in children aged 36-42 months because the nutrients contained in Moringa leaf extract are abundant and varied, such as fat, Vitamin A, Vitamin C, and selenium. Giving Moringa extract to pregnant women provides an abundant supply of micronutrients including $\mathrm{Fe}$, Vitamin A, Vitamin C, and selenium during pregnancy. Therefore, mothers who consume Moringa are filled with micronutrients, such as $\mathrm{Fe}$ in Moringa extract which increases hemoglobin in pregnant women and prevents DNA damage due to oxidative stress [13] [16].

\section{Iron-folic acid supplementation}

Iron-Folic Acid Supplementation during Pregnancy Reduces the Risk of Stunting in Children $<2$ years of Age. The results of the study show that antenatal iron folic acid (IFA) supplementation significantly reduces the risk of stunting in Nepalese children aged $<2$ years. The greatest impact on reducing the risk of child stunting was when IFA supplements were started at 6 months with 90 supplements used. Maternal use of IFA supplements during pregnancy significantly reduced the adjusted risk of stunting by $14 \%$ compared to mothers who never used supplements [17]. The results of this study are in line with Kusmawati's research (2017) that the administration of folic acid can prevent anemia and chronic lack of energy which can lead to stunting [28].

\section{Specific nutrition for pregnant women}

The Relationship of Specific Nutritional Factors in Mothers with Stunting Incidence explained that there was a relationship between the administration of folic acid and iron supplements with the incidence of stunting, folic acid affects body length and heart contractility in zebrafish larvae. Research by Kesumawati and Hidayah (2020), Widyaningrum and Romadhoni (2018), showed that there was a significant relationship between a history of anemia in pregnancy and the incidence of stunting in children under 5 years old [29], [30]. Iron is needed for postnatal growth in the increase of red blood cells and as a building block for the baby's body [31].

\section{Lipid-based nutrient supplements (LNS)}

Prenatal lipid based nutritional supplements can increase birth rates in women, especially those who are at higher risk of developing fetal growth restriction. LNS contains vegetable fat, peanut or peanut paste, and powdered milk and sugar; other ingredients include whey, soy protein isolate, sesame, cashew nuts, and chickpea paste which are used to treat moderate and severe acute malnutrition in infants and young children, LNS is acceptable to infants as well as pregnant and lactating women. LNS is used as complementary food or supplementary food for pregnant women to prevent stunting [32].

PROCOMIDA, a food-assisted maternal and child health (FA-MCHN) and nutrition program

The FA-MCHN and nutrition program can encourage a child's growth during the first 1000 days (pregnancy and the first 2 years of a child's life). The FA-MCHN program can reduce stunting during the first 1000 days, even in populations that are relatively energy/food safe. Large family rations with individual CSB or MNP rations are most effective. The widespread impact as children age highlights the importance of intervening during the full first 1000 days [19].

\section{Preconception nutrition intervention}

The results provide quantitative information about the benefits to fetal growth that can be achieved by increasing intakes of energy, protein, and micronutrients beginning before the second trimester of pregnancy without other interventions directed at improving the poor environment in which the participants live, a relatively large point estimate for the effect. nutritional supplementation initiated 3 months before conception supports increased efforts to improve the nutrition of all women of childbearing age in resource-poor populations in these and similar environments to reduce impaired fetal growth [20].

\section{Antenatal iron-folic acid supplementation}

Antenatal Iron-Folic Acid Supplementation Is Associated with Improved Linear Growth and Reduced Risk of Stunting or Severe Stunting in South Asian Children <2 Years of Age: A Pooled Analysis from Seven Countries, The results of this study explain that stunting and low birth weight are health problems that often occur in children. Stunting in children shows poor nutrition and frequent infections before and after birth which can cause a decline in cognitive function and socio-economic development. Globally, 1 in 5 pregnant women has anemia caused by iron deficiency. In several studies, it has been proven that not only to treat anemia, but IFA supplements are related to baby's weight at birth. A pooled analysis conducted in Nepal found that taking IFA supplements during pregnancy reduced the risk of stunting by $14 \%$. The results of the analysis showed that in seven countries in South 
Asia, IFA antenatal supplementation could reduce the risk of stunting in children $<2$ years of age by $8 \%$ and reduce the severity of stunting by $9 \%$. Consumption of 120 supplements and added IFA supplements during pregnancy at 1-4 months of gestation can reduce the risk of stunting by $14 \%$ and increase body length/age results higher. If only IFA supplements are taken at 1-4 months of gestation, the risk of stunting can be reduced by only $10 \%$ [17].

\section{LNS in the first 1000 days}

LNS in the first 1000 day improves child growth in Bangladesh: A cluster-randomized effectiveness trial, stated that stunting in children is a health problem with a high prevalence that is associated with developmental disorders, increased mortality due to infection, and adverse consequences when children grow up. This study aims to evaluate the effectiveness of communitybased programs as prevention of maternal and child malnutrition within 1000 days of birth. A common program is the provision of nutritional supplements as complementary foods for infants and children. Research using a mixture of micro and macro nutrition products shows a positive effect on children's growth. Lipid-based supplements as additional nutrients play an important role in brain development, immune function and child growth, so that the administration of lipid-based supplements given to mothers and children during the first 1000 days of life can increase growth so that it can be prevented [22].

\section{Prenatal multiple micronutrient supplementation}

Stunting occurs due to lack of nutrition during pregnancy and the failure of the baby's growth to contribute to the risk of stunting in the first 2 years of a child's life. From research conducted in the past three decades, it was found that there are three nutrients that can increase birth weight and reduce the risk of a child being smaller than gestational age so as to prevent stunting. These nutrients are supplements with balanced protein and energy, IFA supplements, and micronutrient supplements. In this study, giving micronutrient supplements to mothers in the pre and postnatal period can increase body length/age in children born and reduce stunting at the age of 3 months of birth [23].

\section{Conclusion}

This review identified that the used media education intervention through demonstrations and direct practice for pregnant women stunting prevention are useful in increasing knowledge of pregnant women in feeding practices, meal preparation, amount of food, energy intake, and protein intake to prevent stunting. We noted there are many kinds of nutrition and supplements such as food from Moringa leaves, Moringa leaf extract supplementation, Moringa powder, and blood-added tablets, IFA, iron and folic acid supplements (IFA), iron supplements, folic acid (IFA), and lipid supplements given to pregnant women can significantly prevent stunting in children. Continuous education and monthly monitoring of pregnant women diet during pregnancy classes at the Posyandu are suggested to prevent stunting in children.

\section{References}

1. Kemenkes RI. Buletin Stunting. Vol. 301. Kementeri Kesehat RI.; 2018. p. 1163-78.

2. Hidayat MS, Pinatih GN. Prevalensi stunting pada balita di wilayah kerja puskesmas sidemen karangasem. E-J Med. 2020;6(7):1-5.

3. Mugianti S, Mulyadi A, Anam AK, Najah ZL. Faktor penyebab anak stunting usia 25-60 bulan di kecamatan sukorejo kota blitar. J Ners Kebidanan. 2018;5(3):268-78. https://doi.org/10.26699/ jnk.v5i3.art.p268-278

4. Yusnita, Jannah F, Aufa A. Hubungan faktor gizi spesifik pada ibu dengan kejadian stunting di kabupaten pandeglang. Semin Nas Ris Inov. 2020;2020:96-101.

5. Kusumawati E, Rahardjo S, Sari HP. Model pengendalian faktor risiko stunting pada anak bawah tiga tahun. Kesmas Natl Public Health J. 2015;9(3):572. https://doi.org/10.21109/kesmas. v9i3.572

6. Alfarisi R, Nurmalasari $Y$, Nabilla S. Status gizi ibu hamil dapat menyebabkan kejadian stunting pada balita. J Kebidanan Malahayati. 2019;5(3):271-8. https://doi.org/10.33024/jkm. v5i3.1404

7. Notoatmodjo S. Promosi Kesehatan dan Perilaku Kesehatan. Jakarta: Rineka Cipta; 2012. p. 45-62.

8. Ho A, Flynn AC, Pasupathy D. Nutrition in pregnancy. Obstet Gynaecol Reprod Med 2016;2016:1-5. https://doi.org/10.1016/j. ogrm.2016.06.005

9. Kominiarek MA, Rajan P. Nutrition recommendations in pregnancy and lactation. Med Clin North Am. 2016;100(6):1199215. https://doi.org/10.1016/j.mcna.2016.06.004 PMid:27745590

10. Damayanti PD, Lestari NT, Gizi BA. Gizi Dalam Daur Kehidupan 2017.

11. JBI. Critical Appraisal Tools Joanna Briggs Institute. Joanna Briggs Institute (JBI); 2020. https://doi. org/10.11124/01938924-201109481-00003

12. Arsyati AM. Pengaruh penyuluhan media audiovisual dalam pengetahuan pencegahan stunting pada ibu hamil di desa cibatok 2 cibungbulang. Promotor. 2019;2(3):1935. https://doi. org/10.32832/pro.v2i3.1935

13. Rohmawati N, Moelyaningrum AD, Witcahyo E. Es krim kelor: Produk inovasi sebagai upaya pencegahan stunting dalam 1000 hari pertama kehidupan (HPK). Randang Tana J Pengabdi Masy. 2019;2(1):10-20. https://doi.org/10.29303/jpmpi.v3i1.392

14. Ningrum NP, Hidayatunnikmah N, Rihardini T. Cegah stunting sejak dini dengan makanan bergizi untuk ibu hamil. E-Dimas $\mathrm{J}$ 
Pengabdi Kpd Masy. 2020;11(4):550-5. https://doi.org/10.26877/ e-dimas.v11i4.5616

15. Leroy JL, Olney D, Ruel M. Tubaramure, a food-assisted integrated health and nutrition program, reduces child stunting in burundi: A cluster-randomized controlled intervention trial. J Nutr. 2018;148(3):445-52. https://doi.org/10.1093/jn/nxx063 PMid:29546306

16. Basri H, Hadju V, Zulkifli A, Syam A, Indriasari R. Effect of moringa oleifera supplementation during pregnancy on the prevention of stunted growth in children between the ages of 36 to 42 months. J Public Health Res. 2021;10(2):2207. https://doi. org/10.4081/jphr.2021.2207

\section{PMid:33855405}

17. Nisar YB, Dibley MJ, Aguayo VM. Iron-folic acid supplementation during pregnancy reduces the risk of stunting in children less than 2 years of age: A retrospective cohort study from Nepal. Nutrients. 2016;8(2):67. https://doi.org/10.3390/nu8020067 PMid:26828515

18. Mridha MK, Matias SL, Chaparro CM, Paul RR, Hussain S, Vosti SA, et al. Lipid-based nutrient supplements for pregnant women reduce newborn stunting in a cluster-randomized controlled effectiveness trial in Bangladesh. Am J Clin Nutr. 2016;103(1):236-49.

PMid:26607935

19. Olney DK, Leroy J, Bliznashka L, Ruel MT. PROCOMIDA, a food-assisted maternal and child health and nutrition program, reduces child stunting in Guatemala: A cluster-randomized controlled intervention trial. J Nutr. 2018;148(9):1493-505. https://doi.org/10.1093/jn/nxy138

PMid:30184223

20. Dhaded SM, Hambidge KM, Ali SA, Somannavar M, Saleem S, Pasha $\mathrm{O}$, et al. Preconception nutrition intervention improved birth length and reduced stunting and wasting in newborns in South Asia: The women first randomized controlled trial. PLoS One. 2020;15(1):e0218960. https://doi.org/10.1371/journal. pone. 0218960

PMid:31995570

21. Nisar YB, Aguayo VM, Billah SM, Dibley MJ. Antenatal ironfolic acid supplementation is associated with improved linear growth and reduced risk of stunting or severe stunting in south asian children less than two years of age: A pooled analysis from seven countries. Nutrients. 2020;12(9):2632. https://doi. org/10.3390/nu12092632

PMid:32872329

22. Dewey KG, Mridha MK, Matias SL, Arnold CD, Cummins JR, Khan MS, et al. Lipid-based nutrient supplementation in the first 1000 d improves child growth in Bangladesh: A cluster-randomized effectiveness trial. Am J Clin Nutr. 2017;105(4):944-57. PMid:28275125

23. Nguyen PH, Gonzalez-Casanova I, Young MF, Truong TV, Hoang $\mathrm{H}$, Nguyen $\mathrm{H}$, et al. Preconception micronutrient supplementation with iron and folic acid compared with folic acid alone affects linear growth and fine motor development at 2 years of age: A randomized controlled trial in Vietnam. J Nutr. 2017;147(8):1593-601. https://doi.org/10.3945/jn.117.250597 PMid:28615372

24. Yoga IT, Rokhaidah. Pengetahuan ibu tentang stunting pada balita di posyandu desa segarajaya. Indones J Health Dev. 2020;2(3):183-92.

25. Khatiwada M, Kartasasmita C, Mediani HS, Delprat C, Van Hal G, Dochez C. Knowledge, attitude and acceptability of the human papilloma virus vaccine and vaccination among University Students in Indonesia. Front Public Health. 2021;9:616456. https://doi.org/10.3389/fpubh.2021.616456 PMid:34195167

26. Aminah $S$, Ramdhan $T$, Yanis $M$. Kandungan nut risi dan sifat fungsional tanam an kelor (Moringa oleifera). Bul Pertan Perkota. 2015;5(2):35-44.

27. Yunitasari E, Pradanie R, Arifin H, Fajrianti D, Lee $B O$. Determinants of stunting prevention among mothers with children aged 6-24 months. Open Access Maced J Med Sci. 2021;9(B):378-84. https://doi.org/10.3889/oamjms.2021.6106

28. Kusumawati I, Indarto D, Hanim D, Suminah S. Hubungan asupan makanan, suplementasi fe dan asam folat dengan kadar hemoglobin pada ibu hamil riwayat kurang energi kronis dan anemia saat menyusui (The relationship of food intake, fe and folic acid supplementation on hemoglobin level in pregnant women). Penelit Gizi Makanan. 2017;39(2):110. https://doi. org/10.22435/pgm.v39i2.5155.103-110

29. Kesumawati D, Hidayah N. Determinants of stunting in children aged 24-59 months in the kasreman community health center. J Vocat Nurs. 2020;1(2):23563. https://doi.org/10.20473/jovin. v1i2.23563

30. Widyaningrum DA, Romadhoni DA. Riwayat anemia kehamilan dengan kejadian stunting pada balita di desa ketandan dagangan madiun. Med Majapahit. 2018;10(2):291.

31. Widianti D, Yusnita. Hubungan Pengetahuan Ibu Terhadap Pemberian Makanan Pendamping Asi (MP-ASI) dengan Kejadian Stunting pada Baduta di; 2020. https://doi. org/10.47560/keb.v9i1.240

32. Das S, Chanani S, More NS, Osrin D, Pantvaidya S, Jayaraman A. Determinants of stunting among children under 2 years in urban informal settlements in Mumbai, India: Evidence from a household census. J Health Popul Nutr. 2020;39:10. https://doi.org/10.1186/s41043-020-00222-x 